\title{
Lyme-meningitt hos barn
}

\section{En svært vanlig årsak til meningitt hos barn er Lyme-borreliose. Det viser en ny populasjonsbasert studie fra Rogaland.}

Studien omfattet alle barn i alderen $3 \mathrm{md}$ - -14 år ved Stavanger universitetssjukehus der det

i perioden 2001-09 ble funnet pleocytose i cerebrospinalvæsken ved spinalpunksjon (1).

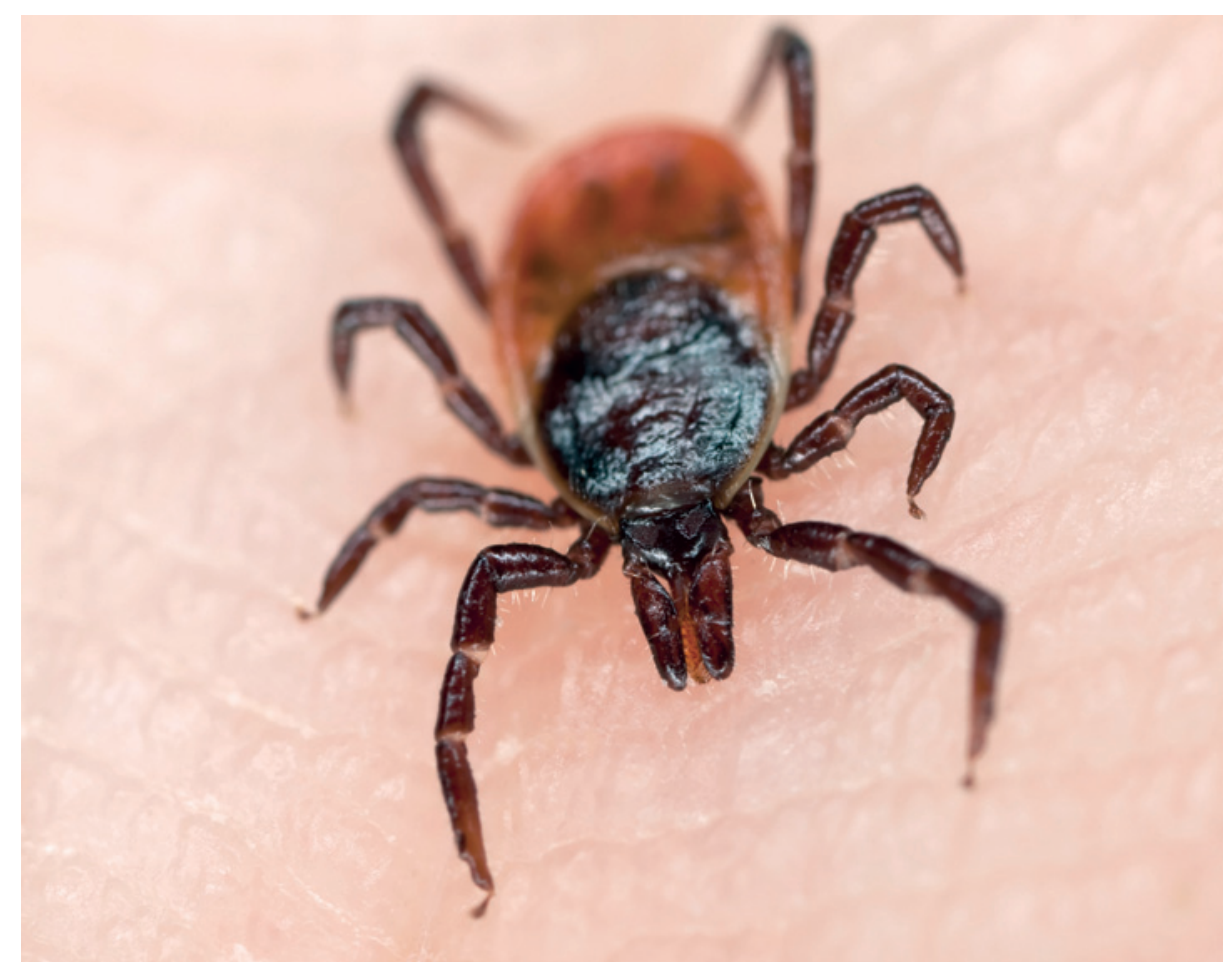

Borreliabakterien overført ved flåttbitt er den vanligste årsaken til meningitt hos barn i Rogaland. Foto Istockphoto/Thinkstock

\section{$\emptyset k t$ risiko for kreft etter Hodgkins lymfom}

\section{De som blir kurert for Hodgkins \\ lymfom, har økt risiko for utvikling av sekundærkreft. Noen synes \\ å være særlig genetisk disponert.}

Både kjemoterapi og strålebehandling gir økt risiko for sekundærkreft. De vanligste kreftformene oppstår i tidligere bestrålt område.

I en ny studie har forskere identifisert tre enkeltbasevariasjoner (SNP) i kromosomregion $6 \mathrm{q} 21$ og 18q11.2 assosiert med utvikling av sekundærkreft hos disse pasientene (1). I forstudier hadde man funnet 665313 interessante enkeltbasevariasjoner. Disse ble undersøkt hos 100 personer som tidligere var behandlet for Hodgkins lymfom og senere hadde utviklet sekundærkreft og hos
89 behandlede som ikke hadde utviklet sekundærkreft. Funnene på 6 q21 ble bekreftet $i$ en annen kohort med 62 pasienter og 71 kontrollpersoner. Forskergruppen undersøkte så sammenhengen mellom aktuelle proteiner og strålebehandling og fant at personer med risikovariantene hadde lavere basalt uttrykk av proteinet PRDM1 og redusert evne til å øke nivået etter strålebehandling.

- Behovet for å identifisere pasienter med øt risiko for stråleindusert sekundærkreft har lenge vært diskutert i litteraturen, sier postdoktorstipendiat Hege Edvardsen ved Institutt for kreftforskning, Oslo universitetssykehus, Radiumhospitalet. - I denne studien identifiserte man to enkeltbasevariasjoner på kromosom 6, sterkt assosiert med utvikling av sekundærkreft.

Studien omfattet relativt få pasienter, men styrkes av at sammenhengen blir bekreftet $i$ et
Totalt ble det diagnostisert 211 barn med infeksiøs meningitt. Av disse fikk $67 \%$ diagnosen nevroborreliose.

Studien er den første i verden som viser Lyme-borreliose som den vanligste årsaken til infeksiøs meningitt hos barn i et geografisk område. I tillegg gir artikkelen nyttig kunnskap om hvordan man på bakgrunn av kliniske funn og foreløpige laboratorieprøver $i$ tidlig fase av utredningen (i påvente av svar på antistoff) kan skille mellom nevroborreliose og annen aseptisk meningitt og dermed kunne bestemme om det skal startes behandling eller ikke. Barn med pleocytose og hjernenerveutfall (vanligvis facialisparese) eller hodepine/nakkestivhet som eneste symptom hadde nær $100 \%$ sannsynlighet for å ha nevroborreliose. Studien viser samtidig at forekomsten av bakteriell meningitt er lav bare 23 barn, dvs. $11 \%$ av alle tilfellene, fikk denne diagnosen i studieperioden.

Rogaland egner seg svært godt til populasjonsbasert epidemiologisk forskning og har høy forekomst av borreliose.

Dag Tveitnes

tvda@sus.no

Knut Øymar

Barneklinikken

Stavanger universitetssjukehus

Litteratur

1. Tveitnes D, Natås OB, Skadberg 0 et al. Lyme meningitis, the major cause of childhood meningitis in an endemic area: a population based study. Arch Dis Child 2012; 97: 215-20. nytt materiale og at funnene kan relateres til endringer i fenotype, nemlig nivået av proteinet PRDM1. PRDM1 er et tumorsuppressorgen som er involvert i proliferasjon og apoptose. Det er ofte tapt i ulike krefttyper, og personer med et lavere nivå av proteinet kan således ha økt risiko for utvikling av sekundærkreft. Studien gir spennende innsikt, men det gjenstår å se hvordan dette kan benyttes i klinisk praksis, sier Edvardsen.

\section{Åslaug Helland}

aslaug.helland@gmail.com

Tidsskriftet

\section{Litteratur}

1. Best T, Li D, Skol AD et al. Variants at $6 q 21 \mathrm{impli}$ cate PRDM1 in the etiology of therapy-induced second malignancies after Hodgkin's lymphoma. Nat Med 2011; 17: 941-3. 